\title{
TP53 Loss of Nuclear Expression
}

National Cancer Institute

\section{Source}

National Cancer Institute. TP53 Loss of Nuclear Expression. NCI Thesaurus. Code C160422.

An indication that expression of TP53 was not detected in the nuclei of cells in a sample. 